\section{Australian Journal of \\ Crop Science}

\title{
Accumulation of nitrogen, phosphorus and potassium in sugarcane cultivated under different types of water management and doses of nitrogen
}

\author{
Andréa Raquel Fernandes Carlos da Costa ${ }^{1}$, Mário Monteiro Rolim ${ }^{1}$, Edna Maria Bonfim-Silva ${ }^{2 *}$, \\ Djalma Euzébio Simões Neto ${ }^{3}$, Elvira Regis Maria Pedrosa ${ }^{1}$, Ênio Farias França e Silva ${ }^{1}$
}

\author{
${ }^{1}$ Department of Agricultural Engineering, University Federal Rural of Pernambuco, 52.171-900, Recife, \\ Pernambuco, Brazil \\ ${ }^{2}$ Institut of Agricultural Sciences and Technology Federal University of Mato Grosso Department of Agricultural \\ and Environmental Engineering, Rondonopolis, Mato Grosso, Brazil \\ ${ }^{3}$ Sugarcane Experimental Station of Carpina, University Federal Rural of Pernambuco, 55.810-700, Recife, \\ Pernambuco, Brazil
}

*Corresponding author: embonfim@hotmail.com

\begin{abstract}
Availability of water in soil together with an adequate supply of nitrogen are factors that can influence the accumulation and storage of nutrients by plants, making it essential for the growth and development of crops. Thus, this study aimed to evaluate the effects of different types of water managements $(\mathrm{M})$ and application of varying doses of nitrogen $(\mathrm{N})$ in dry biomass accumulation (DB), nitrogen $(\mathrm{N})$, phosphorus $(\mathrm{P})$ and potassium $(\mathrm{K})$, in the different organs of the sugarcane plant (leaf, tip and culm). The treatments consisted of four types of water management $\left(14,980,16,140,17,390\right.$ and 18,540 $\mathrm{m}^{3} \mathrm{ha}^{-1}$, during the crop cycle), and five doses of nitrogen $\left(0,20,40,80\right.$ and $\left.120 \mathrm{~kg} \mathrm{ha}^{-1}\right)$ arranged in strips and designed in randomized blocks with four replications. Availability of water provided an increase in dry biomass accumulation of leaf, and nitrogen fertilization increased dry biomass accumulation of leaf and culm in sugarcane. Nitrogen fertilization at time of planting increased the accumulation of nitrogen and phosphorus in the leaf, tip and culm, and of potassium in the leaves of the sugarcane plant. Availability of water increased the accumulation of potassium in the leaves of the sugarcane plant.
\end{abstract}

Keywords: Saccharum spp.; water availability; nitrogen fertilization; dry matter; nutrients.

Abbreviations: DB_dry biomass accumulation; N_nitrogen; K_potassium; P_phosphorus; M_water managements; EECAC_Sugarcane Experimental Station of Carpina; UFRPE_Rural Federal University of Pernambuco; DAP_days after planting; Ia_intensity of application of the irrigation system; Vi: irrigation water volume based on crop evapotranspiration; Vw_water volume applied through irrigation during the crop cycle; R_rainfall during the experiment; Vt: full water volume; pH_hydrogen potential; Ca_calcium; Mg_magnesium; H_hydrogen; Al_aluminum; CEC_cation exchange capacity; V_base saturation; $\mathrm{m} \_$aluminum

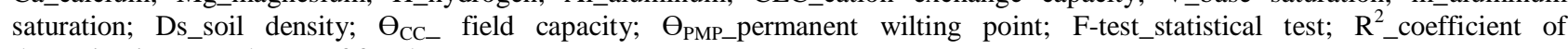
determination; $\mathrm{DF} \_$degree of freedom.

\section{Introduction}

For the establishment of an adequate level of nutrition to plants, it is necessary to understand the normal patterns of nutrient accumulation in dry biomass. However, the amount and the proportion of accumulated nutrients are functions characteristic of the plant and to external factors that influence this process. Nutrients extracted from the soil and accumulated by the plants vary according to cultivar, soil management, crop cycle and other available inputs for the development of plants (Bennett et al., 2013). In sugarcane culture, nitrogen is the most required nutrient, and it is essential for vigorous, vegetative growth, yield and crop quality. The importance of the nitrogen for this culture is related to plants being framed among grasses with the highest photosynthetic efficiency, namely, they are ranked among C4-metabolism plants, characterized by a high photosynthetic rate, and by efficient use of $\mathrm{N}$ and solar energy, and being highly effective in the production of dry biomass (Franco et al., 2010). According to Otto et al. (2009), nitrogen fertilization promotes a significant increase in the dry biomass of sugarcane's aerial parts. Almeida Júnior et al. (2011) also observed the influence of nitrogen fertilization on the production of dry biomass from sugarcane. Sugarcane, being a culture that produces high volumes of biomass, requires substantial inputs of water and nitrogen to achieve high yields (Freitas et al., 2012). Thus, the use of an irrigation technology and nitrogen fertilization makes it imperative for the improvement of plant development considering its genetic potential (Dantas Neto et al., 2006; Farias et al., 2008). The availability of water in the soil, in addition to being crucial to the growth and development of the numerous cultures (Lawlor and Cornic, 2002), affects the efficiency of fertilization, it being necessary to promote solubility and the subsequent release of nutrients to the plant. According to Oliveira et al. (2010a), the average export of nitrogen, phosphorus and potassium by the culm of irrigated sugarcane varieties is 92,15 and $188 \mathrm{~kg} \mathrm{ha}^{-1}$, respectively. Thus, optimal water conditions coupled with an adequate supply of nitrogen can promote root growth (Robinson et al., 2010), 
contributing to the absorption of nutrients by sugarcane. Thus, besides increasing the production of sugarcane culm, nitrogen fertilization and water availability can generate a synergistic effect on the absorption of other nutrients as well (Franco et al., 2007), which would lead components of plants to accumulate nutrients at appropriate levels, making them better nourished, enabling optimum sugarcane yield and quality of sugar, not only in a production cycle but also with an additive effect on subsequent cycles, providing it with a greater longevity (Oliveira, 2011a). According to Vale et al. (2011), nitrogen and phosphorus are the nutrients that most limit the growth of sugarcane. Nitrogen deprivation results in the highest limitation of growth when compared with other macronutrients, because nitrogen has a structural function participating in various organic compounds and vital physiological processes (Prado et al., 2010). In this context, knowledge of the amount of accumulated nutrients in the plant provides information that will assist in fertilizer management. It will also help to improve crop productivity through the increase in total biomass production, improving transfer of assimilates to the plant's harvested parts, and favoring the efficient use of fertilizers (Carmo et al., 2011). Thus, more research aimed at quantifying and allocating nutrients to the various organs in the shoot of the sugarcane is necessary. Thus, this study aimed to evaluate the effects of water managements and nitrogen doses in dry biomass accumulation, nitrogen, phosphorus and potassium in the various organs (leaf, tip and culm) of sugarcane.

\section{Results and Discussion}

\section{Analysis of variance}

Table 1 gives a summary of the analysis of variance for dry biomass accumulation $(\mathrm{DB}$, nitrogen $(\mathrm{N})$, potassium $(\mathrm{K})$ and phosphorus $(\mathrm{P})$ in the leaf, tip and culm of sugarcane in function of water managements $(\mathrm{M})$ and nitrogen doses. There was a significant effect of interactions between water managements and nitrogen on the accumulation of nitrogen in the tip of sugarcane. It was also found that water management influenced isolated dry biomass, potassium and phosphorus accumulation by sugarcane leaves, and the doses of nitrogen influenced dry biomass accumulation of leaves and culms, nitrogen, potassium and phosphorus accumulation in leaves and the accumulation of nitrogen and phosphorus in the tips and culms of the plant.

\section{Dry biomass accumulation}

Evaluating the leaf dry biomass accumulation in function of water managements, there was an adjustment to the linear regression model, with an increase in response to total water contents available. The highest accumulation of dry biomass (14.35 $\mathrm{Mg} \mathrm{ha}^{-1}$ ) was obtained with $18,540 \mathrm{~m}^{3} \mathrm{ha}^{-1}$, while the lowest $\left(10.80 \mathrm{Mg} \mathrm{ha}^{-1}\right)$ was obtained with $14.980 \mathrm{~m}^{3} \mathrm{ha}^{-1}$ with an increase of $32.87 \%$ in dry biomass accumulation of sugarcane leaves (Fig. 1A). According to Calheiros et al. (2011), availability of water extends a plant's photosynthetic activity, resulting in a greater accumulation of dry biomass. The stages of growth and development of sugarcane require high availability of water, as well as the plant's morphological characteristics that favor interception of solar radiation (Bonnett et al., 2006). Thus, irrigation at the tilling stage together with plant growth favor the development of a plant's genetic potential, confirming its ability to capture solar radiation and convert it into dry biomass (Oliveira et al., 2010b). For accumulation of dry biomass in the culm and tip, no regression equation adjustments were possible; average values of 48.08 and $3.56 \mathrm{Mg} \mathrm{ha}^{-1}$, respectively, were obtained.

Regarding the effect of nitrogen doses on dry biomass accumulation in the plant's organs (Fig. 1B), a linear response to the accumulation of dry biomass of culms and leaves was also observed with an increase in nitrogen doses. The highest dry biomass accumulation observed (65.43 and $18.38 \mathrm{Mg} \mathrm{ha}^{-1}$ ) were obtained with a $120 \mathrm{~kg} \mathrm{ha}^{-1}$ nitrogen dose, and the lowest (47.43 and 9.26 $\mathrm{Mg} \mathrm{ha}^{-1}$ ) were obtained when nitrogen fertilization was not applied, with an increase of 37.95 and $98.49 \%$ of dry biomass to culm and leaf, respectively. Thus, our findings are in agreement with those of Bologna-Campbell et al. (2013), studying the effect of nitrogen doses $\left(0,40,80\right.$ and $\left.120 \mathrm{~kg} \mathrm{ha}^{-1}\right)$ in plant cane, observed that a $120 \mathrm{~kg} \mathrm{ha}^{-1}$ nitrogen dose increased dry biomass production in the plant's aerial part by $37 \%$ when compared with treatments without nitrogen fertilization. In an evaluation conducted at the end of the cycle, Trivelin et al. (2002) found a linear increase in dry biomass of the aerial parts of sugarcane (plant cane) in response to application of nitrogen. Nitrogen is an essential nutrient in plant metabolism because it is used in the synthesis of proteins and other organic compounds. These findings are in accordance with those of Marschner (2012), more than $90 \%$ of the plant's dry biomass consists of organic compounds such as cellulose, starch, lipids and proteins, and the production of dry biomass is directly related to photosynthesis, which is the primary process for the synthesis of these organic compounds in green plants. Dry biomass accumulation in the tip of sugarcane was not influenced by nitrogen doses, presenting a $3.56 \mathrm{Mg} \mathrm{ha}^{-1}$ mean value. Overall, in this study, it was observed that the dry biomass accumulation of a plant's aerial parts was higher in the culm than in other plant organs. These results also support the results recorded by Rengel et al. (2011) in order to evaluate the growth of sugarcane in an area planted with the RB855035 variety, who also found that the dry biomass accumulation at the end of the cycle was higher in the culm. According to the authors, at the end of the cycle, the plant accumulated $43.7 \mathrm{Mg} \mathrm{ha}^{-1}$ of dry biomass in shoots, with $75.1 \%$ corresponding to the culm and $24.9 \%$ to leaf tissue. For these authors, from 185 days after planting, an increased production of culms begins about the issuance of leaves, resulting in a rapid increase in production of dry biomass. Oliveira et al. (2010b) observed that, from 120 days after planting, the amount of accumulated dry biomass in sugarcane's culm becomes greater than that accumulated in the leaf and tip, maintaining the higher level until the end of the crop cycle.

\section{Accumulation of nitrogen in sugarcane}

The accumulation of nitrogen in the leaf, tip and culm is shown in Fig. 2A, 2B and 2C, respectively. There was a significant increase with the addition of nitrogen doses on the accumulation of nitrogen in the leaf and the culm of the plant (Fig. 2A and 2C). The highest accumulation (121.01 and $258.74 \mathrm{~kg} \mathrm{ha}^{-1}$ ) was observed in plants fertilized with a 120 $\mathrm{kg} \mathrm{ha}^{-1}$ nitrogen dose, and the lowest accumulation (63.53 and $160.7 \mathrm{~kg} \mathrm{ha}^{-1}$ ) was observed in plants that did not receive nitrogen fertilization for leaf and culm, respectively.

The highest accumulation of the maximum dose of the experimental range can be explained by a higher availability of nitrogen, as well as by a higher production of dry biomass at that dosage. Vale et al. (2013), applied different doses of 
Table 1. Summary of the analysis of variance for dry biomass accumulation (DB), nitrogen (N), potassium (K) and phosphorus (P) in the leaf, tip and culm of sugarcane in function of water managements $(M)$ and nitrogen doses $(N)$.

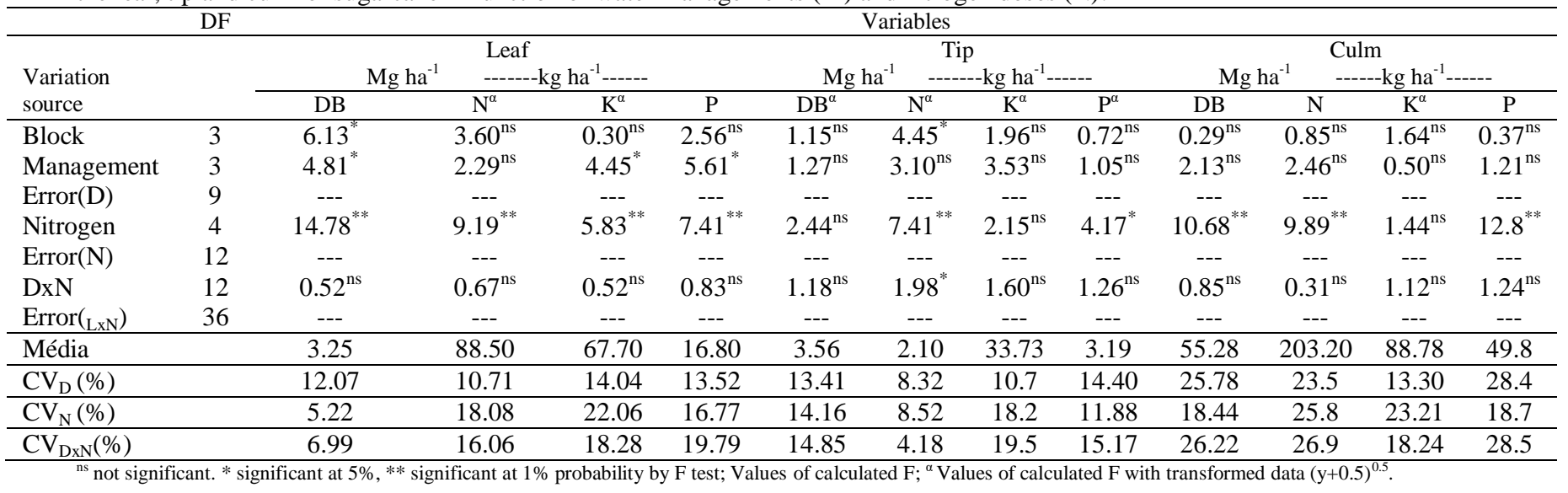

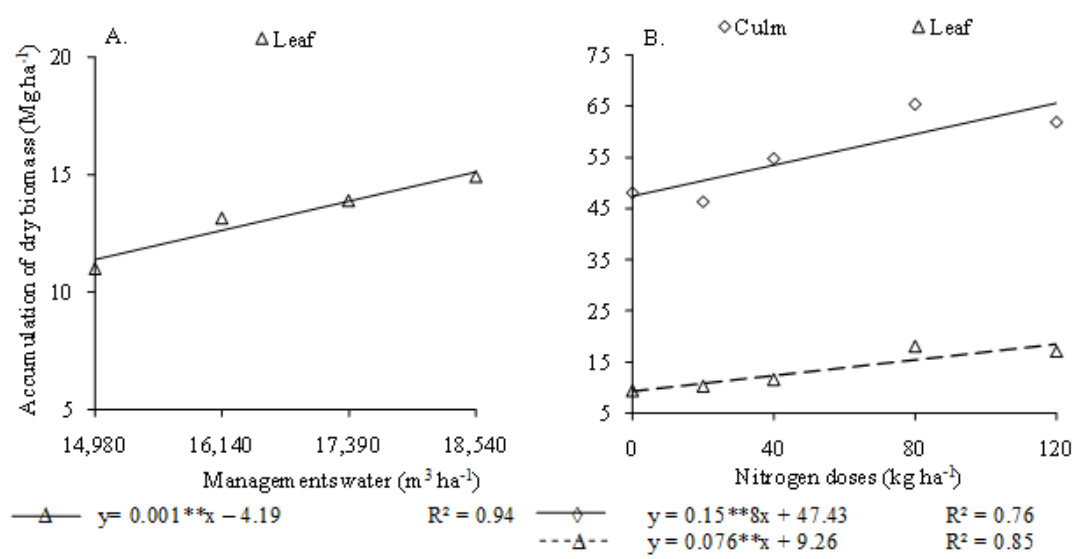

Fig 1. Dry biomass accumulation of the leaf and culm of sugarcane (plant cane), RB92579 variety, in function of water managements (A) and nitrogen doses (B).

Table 2. Chemical and physical characterization of the soil from the experimental area before the experiment.

\begin{tabular}{|c|c|c|c|c|c|c|c|c|c|c|}
\hline \multirow{3}{*}{$\begin{array}{l}\text { Layer } \\
\text { m }\end{array}$} & \multicolumn{10}{|c|}{ Chemical analysis } \\
\hline & $\mathrm{pH}$ & $\mathrm{P}$ & $\mathrm{H}+\mathrm{AL}$ & $\mathrm{Al}^{3+}$ & $\mathrm{Ca}^{2+}$ & $\mathrm{Mg}^{2+}$ & $\mathrm{K}^{+}$ & $\mathrm{CTC}^{(1)}$ & $\mathrm{V}^{(2)}$ & $\mathrm{m}^{(3)}$ \\
\hline & $\mathrm{H}_{2} \mathrm{O}$ & $\mathrm{mg} \mathrm{dm}^{-3}$ & \multicolumn{6}{|c|}{ - } & \multicolumn{2}{|c|}{-----.\%----- } \\
\hline $0-0.20$ & 5.18 & 17.5 & 3.45 & 0.25 & 1.67 & 1.63 & 0.15 & 6.99 & 50.64 & 6.57 \\
\hline $0.20-0.40$ & 5.06 & 17.0 & 4.00 & 0.30 & 1.67 & 1.13 & 0.15 & 7.05 & 43.26 & 8.85 \\
\hline \multirow{2}{*}{ Layer } & \multicolumn{10}{|c|}{ Physical analysis } \\
\hline & $\mathrm{Ds}^{(4)}$ & Sandy & Silt & Clay & $\Theta_{\mathrm{CC}}^{(5)}$ & $\Theta_{\mathrm{PMP}}{ }^{(6)}$ & \multicolumn{4}{|c|}{ Textural class } \\
\hline $\mathrm{m}$ & $\mathrm{Mg} \mathrm{m}^{-3}$ & \multicolumn{3}{|c|}{--------------g kg-1----------- } & \multicolumn{2}{|c|}{$---m^{-3} m^{-3}--$} & & & & \\
\hline $0-0.20$ & 1.72 & 848.7 & 13.9 & 137.4 & 0.15 & 0.10 & \multicolumn{4}{|c|}{ Sandy loam } \\
\hline $0.20-0.40$ & 1.86 & 826.2 & 16.4 & 157.4 & 0.18 & 0.12 & \multicolumn{4}{|c|}{ Sandy loam } \\
\hline
\end{tabular}

Table 3. Irrigation system evaluation results and volume of water applied.

\begin{tabular}{lllllll}
\hline Managements & $\mathrm{Ia}\left(\mathrm{m}^{3} \mathrm{ha}^{-1} \mathrm{~h}^{-1}\right)$ & $\mathrm{Vi}(\%)$ & $\mathrm{Vw}\left(\mathrm{m}^{3} \mathrm{ha}^{-1}\right)$ & $\mathrm{V}\left(\mathrm{m}^{3} \mathrm{ha}^{-1}\right)$ & ${\mathrm{R}\left(\mathrm{m}^{3} \mathrm{ha}^{-1}\right)}_{\mathrm{Vt}\left(\mathrm{m}^{3} \mathrm{ha}^{-1}\right)}$ \\
\hline $\mathrm{M}_{0}$ & 0.0 & 0.0 & 0.0 & 1,380 & 13,600 & 14,980 \\
$\mathrm{M}_{1}$ & 960.0 & 48.0 & 1,160 & 1,380 & 13,600 & 16,140 \\
$\mathrm{M}_{2}$ & 1,850 & 100.0 & 2,410 & 1,380 & 13,600 & 17,390 \\
$\mathrm{M}_{3}$ & 2,780 & 150.0 & 3,560 & 1,380 & 13,600 & 18,540 \\
\hline
\end{tabular}

Ia: intensity of application of the irrigation system; Vi: irrigation water volume based on crop evapo-transpiration; Vw: water volume applied through irrigation during the crop cycle $\left(\mathrm{m}^{3}\right)$; R: rainfall during the experiment; V: initial water volume applied; Vt: full water volume $\left(\mathrm{m}^{3} \mathrm{ha}^{-1}\right)$

Table 4. Culture coefficients (Kc) for sugarcane plants during different periods of development.

\begin{tabular}{ll}
\hline Plant cane & Kc \\
\hline Days & 0.40 \\
$1-61$ & 0.75 \\
$62-153$ & 1.10 \\
$154-244$ & 1.25 \\
$245-334$ & 0.70 \\
$335-360$ & \\
\hline
\end{tabular}



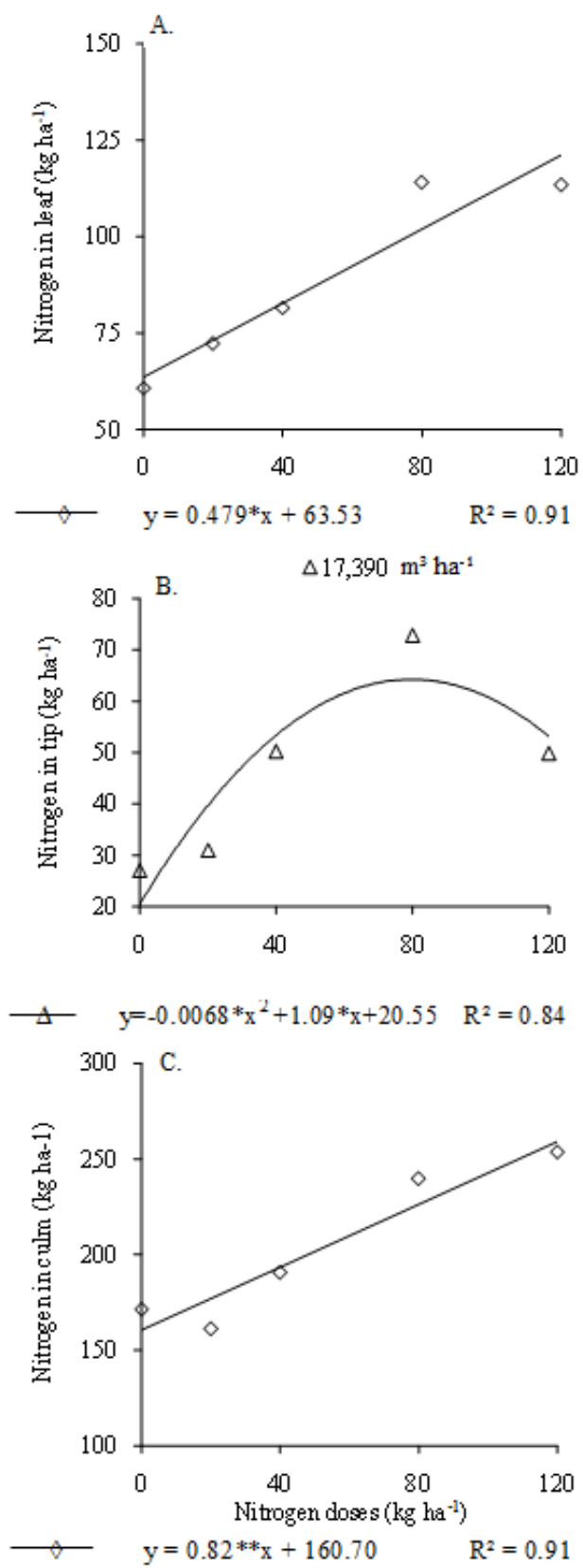

Fig 2. Nitrogen accumulation in the leaf (A), tip (B) and culm (C) of sugarcane (plant cane), RB92579 variety, in function of nitrogen doses.

nitrogen $\left(0,60,120,180\right.$ and $\left.240 \mathrm{~kg} \mathrm{ha}^{-1}\right)$ in a sugarcane crop, and evaluated their effect on the concentration of nitrogen in the leaves. They also observed that the accumulation of nitrogen in green leaves and culms incremented with increasing doses; with 122 and $167 \mathrm{~kg} \mathrm{ha}^{-1}$ doses, the maximum accumulation of nitrogen (96.3 and 98.8 $\mathrm{kg} \mathrm{ha}^{-1}$ ) was obtained. Franco et al. (2007), evaluating the accumulation of macronutrients in the shoots of sugarcane in function of nitrogen fertilization, also found that nitrogen had significantly accumulated in larger amounts in function of nitrogen doses applied, and that this accumulation showed a linear response. The highest accumulation of nitrogen observed in the study was similar to that found by Oliveira et al. (2011b), which, evaluating the extraction of nutrients by sugarcane varieties, observed that the RB92579 variety extracted an average of $260 \mathrm{~kg} \mathrm{ha}^{-1}$ of nitrogen, but this extraction was for the $80 \mathrm{~kg} \mathrm{ha}^{-1}$ nitrogen dose. Of great importance to the plant, nitrogen is an essential constituent of amino acids, the main constituents of proteins, which, besides playing a role in cell division and production of chlorophyll (Malavolta, 2006), contribute to the growth and development of the plant. For the effect of the interaction between water management and nitrogen doses on nitrogen accumulation in sugarcane's tip, there was a significant effect in response to nitrogen doses at the $17,390 \mathrm{~m}^{3} \mathrm{ha}^{-1}$, with an adjusted quadratic regression equation (Fig. 2B). The maximum accumulation of nitrogen $\left(64.55 \mathrm{~kg} \mathrm{ha}^{-1}\right)$ was obtained in the $80 \mathrm{~kg} \mathrm{ha}^{-1}$ nitrogen dose, then decreasing to a $55.91 \mathrm{~kg} \mathrm{ha}^{-1}$ accumulation at a $120 \mathrm{~kg} \mathrm{ha}^{-1}$ nitrogen dose. Thus, there was an increase of $214.1 \%$ in nitrogen accumulation in the sugarcane tip from the absence of nitrogen fertilizer to the 80 $\mathrm{kg} \mathrm{ha}^{-1}$ nitrogen dose. Nitrogen absorbed by the roots can be directly transported by mass flow to the aerial parts of the plant, where its assimilation occurs (Silva and Casagrande, 1983). However, the accumulation of nutrients in different organs of the plant shows variations depending on metabolic and physiological activities of these organs (Minami and Haag, 2003). The main function of leaves and culms, for example, is to serve as the site in which photosynthesis occurs, a process that depends on good water conditions and an adequate supply of nitrogen, favoring the accumulation of nutrients in this organ as a result of the demand to perform this process, which will then promote the plant's growth and development. At 14,980, 16,140 and $18,540 \mathrm{~m}^{3} \mathrm{ha}^{-1}$ water management, there was no effect of nitrogen fertilization on the accumulation of nitrogen in the plant tip, with average values of $38.34,42.94$ and $41.03 \mathrm{~kg} \mathrm{ha}^{-1}$, respectively. When water stress increases, either by an excess or shortage of water, the response to fertilization decreases (Carvalho et al., 2009). Through the results of this study, it was observed that the accumulation of nitrogen in the plant's culm was higher than the nitrogen incorporated into the soil via fertilization. This may have occurred as a result of nitrogen entering the soil through other sources such as mineralization of organic matter, culture residues present in the soil, rainfall and biological fixation of atmospheric $\mathrm{N}_{2}$ by microorganisms (Taiz and Zeiger, 2013). For accumulation of phosphorus in the plant's organs, there was a quadratic regression model for accumulation of phosphorus in the leaf of sugarcane in the function of water management. The maximum accumulation of phosphorus in the leaf $\left(19.13 \mathrm{~kg} \mathrm{ha}^{-1}\right)$ was observed at the management of $17,560 \mathrm{~m}^{3} \mathrm{ha}^{-1}$, an increase of $37.43 \%$ over the $14,980 \mathrm{~m}^{3} \mathrm{ha}^{-1}$ management $\left(13.92 \mathrm{~kg} \mathrm{ha}^{-1}\right)$, with a subsequent reduction, reaching up to the $18,540 \mathrm{~m}^{3} \mathrm{ha}^{-1}$ management an accumulation of $18.4 \mathrm{~kg} \mathrm{ha}^{-1}$ of phosphorus in the leaf (Fig. 3A). The high solubility of organic salts in water favors the absorption of nutrients by plants, but the excess water may be detrimental by promoting leaching of nutrients. There was also an effect of nitrogen doses on accumulation of phosphorus in the leaf, adjusting the linear regression equation, being the highest accumulation $(22.5 \mathrm{~kg}$ $\mathrm{ha}^{-1}$ ) observed at the $18,540 \mathrm{~m}^{3} \mathrm{ha}^{-1}$ management, and the lowest accumulation of phosphorus $\left(12.42 \mathrm{~kg} \mathrm{ha}^{-1}\right)$ at the $14,980 \mathrm{~m}^{3} \mathrm{ha}^{-1}$ management (Fig. 3B). According to Campbell (2000), basic nitrogen functions favor the growth and the dark green color of plants. They are a constituent of proteins and enzymes and promote the development of the root system, improving the absorption of other nutrients present in the soil solution. That is what probably occurred in this study, in which the use of nitrogen doses favored the development of the root system and, consequently, the absorption of nutrients such as phosphorus and potassium. 

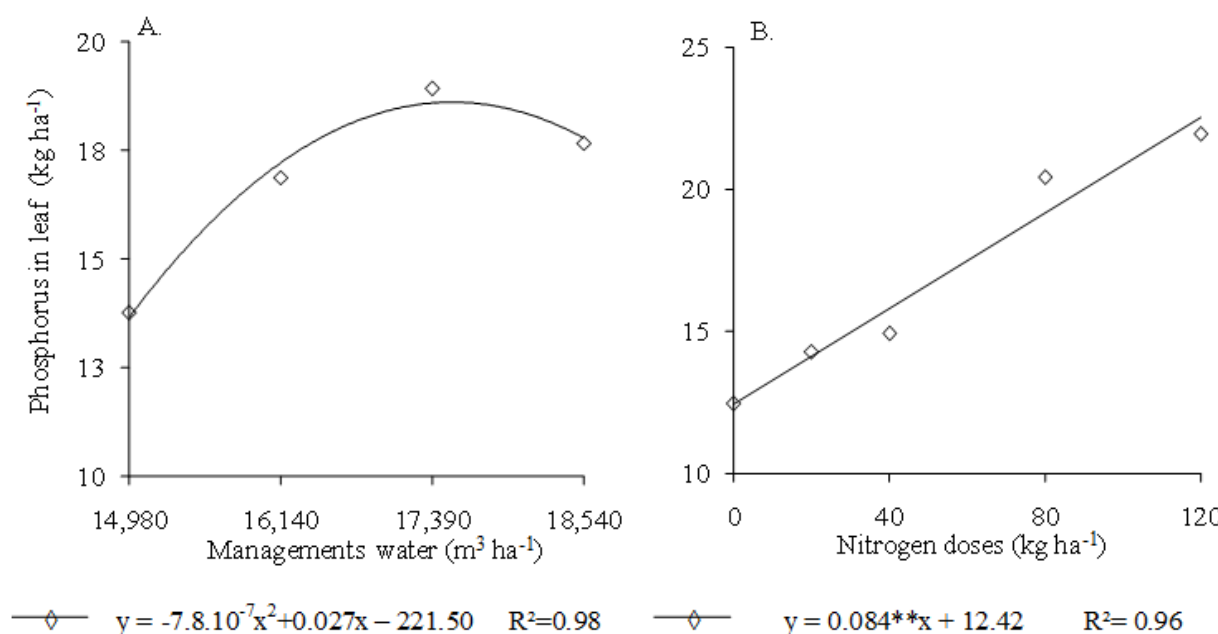

$\longrightarrow \quad y=-7.8 .10^{-7} x^{2}+0.027 x-221.50 \quad R^{2}=0.98$

$\longrightarrow \quad \mathrm{y}=0.084^{* *} \mathrm{x}+12.42 \quad \mathrm{R}^{2}=0.96$

Fig 3. Phosphorus accumulation in leaf of sugarcane (plant cane) in function of water managements (A) and nitrogen doses (B).
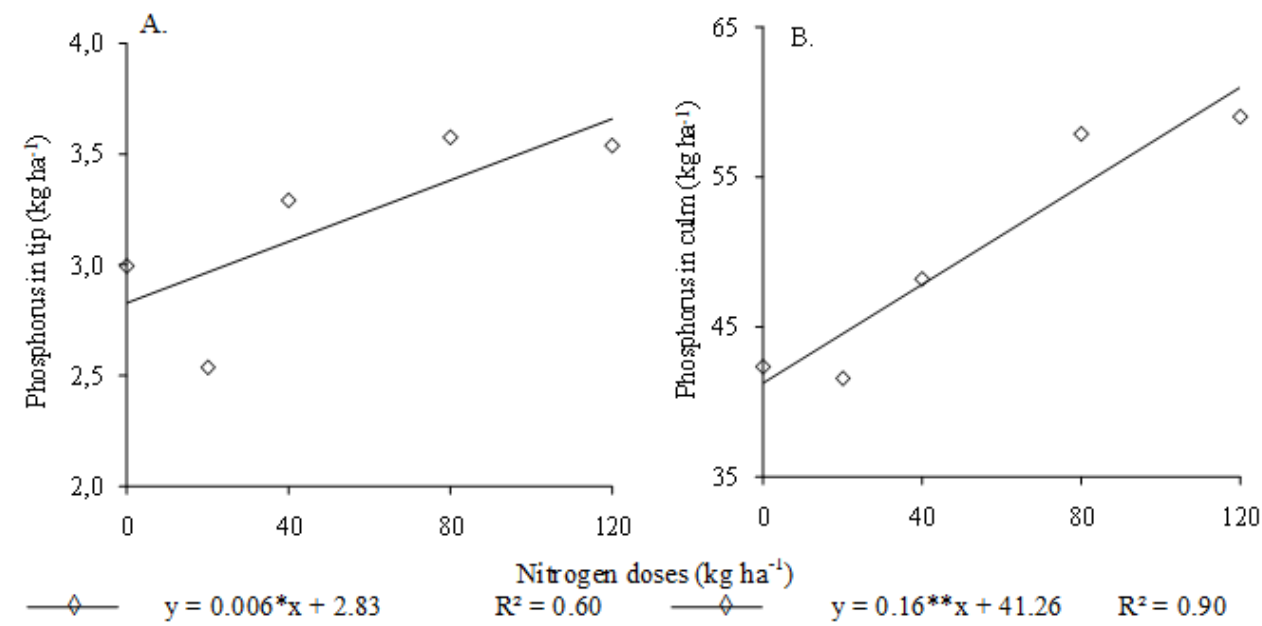

Fig 4. Phosphorus accumulation in the leaf (A) and culm (B) of sugarcane (plant cane), RB92579 variety, in function of nitrogen doses.
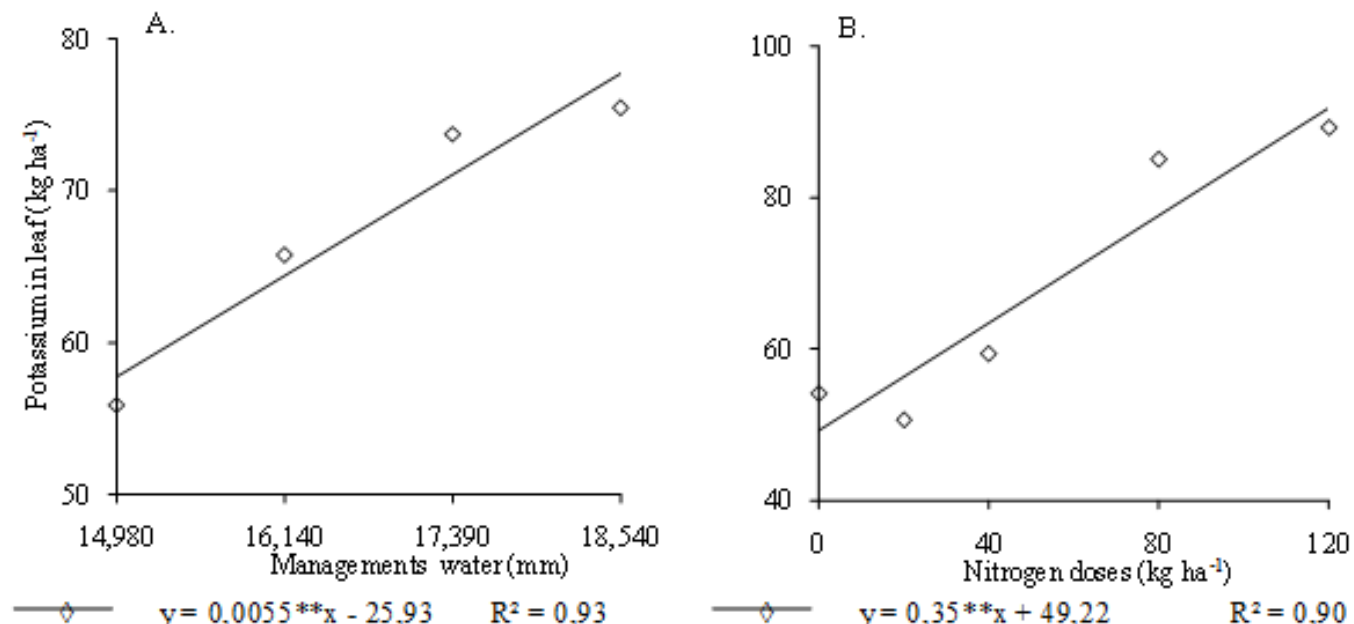

Fig 5. Potassium accumulation in the leaf of sugarcane (plant cane), RB92579 variety, in function of water managements (A) and nitrogen doses (B). 


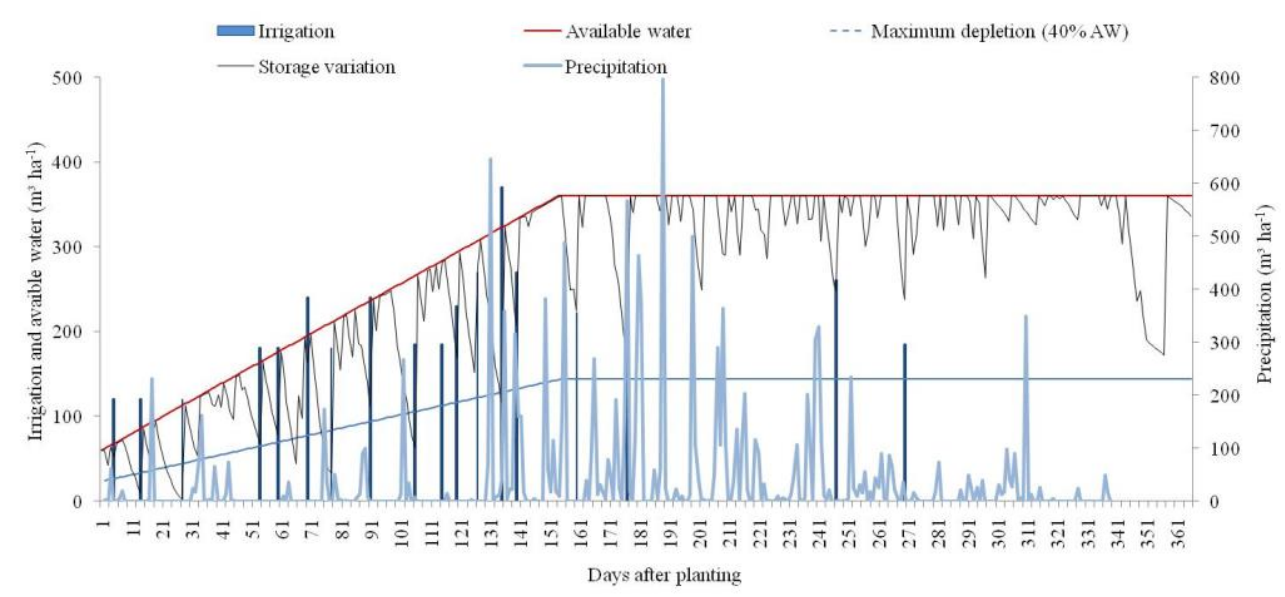

Fig 6. Water balance during the cultivation of plant cane.

\section{Accumulation of phosphorus in sugarcane}

For accumulation of phosphorus in the tip and culm (Fig. 4A and 4B), a linear response was also found in accordance with the increase in nitrogen fertilization, with the highest accumulation of phosphorus in the tip and culm (3.55 and $60.94 \mathrm{~kg} \mathrm{ha}^{-1}$ ) observed at a $120 \mathrm{~kg} \mathrm{ha}^{-1}$ nitrogen dose, and the lowest ( 2.83 and $41.26 \mathrm{~kg} \mathrm{ha}^{-1}$ ) being observed without nitrogen fertilization, respectively. Regarding accumulation of potassium, a significant response was observed only for potassium accumulated in the leaf depending on water management and nitrogen doses (Fig. 5A and 5B). The highest accumulation of potassium in sugarcane leaves in function of water availability was observed with $18,540 \mathrm{~m}^{3}$ $\mathrm{ha}^{-1}\left(76.04 \mathrm{~kg} \mathrm{ha}^{-1}\right)$, and the lowest accumulation of potassium $\left(56.46 \mathrm{~kg} \mathrm{ha}^{-1}\right)$ was observed with $14,980 \mathrm{~m}^{3} \mathrm{ha}^{-1}$, with an increase of $34.68 \%$ from the lowest to the highest levels of water available (Fig. 5A).

According to Dalri et al. (2008), as the availability of water in the soil increases, the efficiency of nutrient absorption also increases, especially with high-solubility nutrients such as nitrogen and potassium, since these will be available to the plants in the soil solution, thus facilitating the process of absorption.

\section{Accumulation of potassium in sugarcane}

For accumulation of potassium in leaves in function of nitrogen fertilization, a linear increase was also observed, with an $86.55 \%$ increase from the absence of nitrogen $(49.22$ $\mathrm{kg} \mathrm{ha}^{-1}$ ) to the $120 \mathrm{~kg} \mathrm{ha}^{-1}$ nitrogen dose $\left(91.82 \mathrm{~kg} \mathrm{ha}^{-1}\right.$ ) (Fig. $5 \mathrm{~B})$.

Franco et al. (2010) also found a linear increase in accumulation of potassium in sugarcane leaves with the use of increasing doses of nitrogen $\left(40,80\right.$ and $120 \mathrm{~kg} \mathrm{ha}^{-1}$ as urea). Potassium is essential for plant growth and greatly required during the growth, reproductive and vegetative states since it engages in osmotic adjustment, stomatal mechanism, photosynthesis, enzyme activation and meristem growth (Figueiredo, 2006). According to Brar et al. (2011), nitrogen is a potent stimulant of plant growth. However, to achieve maximum efficiency in agricultural production, an appropriate amount of potassium must be available in the soil since there is a strong interaction between these two nutrients in the growth of a culture. In general, it was observed that the culm was the organ that accumulated most nutrients. From the moment when the plant starts to grow, there is an increase in the absorption of nutrients. The highest dry biomass accumulation rate and nutrients registered in the culm suggest that these were the preferred drains of the plant.

\section{Materials and Methods}

\section{Plant materials}

Planting was done manually using seedlings of the RB92579 sugarcane variety. The seedlings were distributed, leaving three buds per grindstone (tholepin). Tholepins were distributed within the planting rows, totaling 18 buds per linear meter. The experimental plots were 10 rows of sugarcane plants, spaced $1.10 \mathrm{~m}$ apart, $6.0 \mathrm{~m}$ long, totaling an area of $66.0 \mathrm{~m}^{2}$ and a floor area of $39.6 \mathrm{~m}^{2}$, over a total of 80 experimental plots.

\section{Localization and characterization of the experimental area}

The experiment was conducted in the field, in the agricultural area of the Sugarcane Experimental Station of Carpina, a research unit of the Rural Federal University of Pernambuco (UFRPE) located in Carpina, PE (7 $51^{\prime} 13^{\prime \prime} \mathrm{S}, 35^{\circ} 14^{\prime} 10^{\prime \prime} \mathrm{W}$, $180 \mathrm{~m}$ above sea level), from November 2012 to November 2013. The chemical and physical characterization of the soil was determined before the installation of the experiment in the $0-0.20$ and $0.20-0.40 \mathrm{~m}$ layers, according to Embrapa (1997) (Table 2). The soil of the experimental area was classified as a Dystrophic Abrupt Ultisol (Embrapa, 2013).

\section{Soil preparation and fertilization}

Soil preparation was carried out 15 days prior to the commencement of the experiment and consisted of harrowing (harrow and leveling harrows) used for soil loosening, destruction of crop residues, lime incorporation, organization of the area and subsequent opening of the planting rows. For soil correction, limestone at a $465 \mathrm{~kg} \mathrm{ha}^{-1}$ dose was applied. Upon calculating the amount of limestone, the method of neutralization of exchangeable aluminum was used. Fertilization took place in the foundation on the planting day, with phosphorus $\left(\mathrm{P}_{2} \mathrm{O}_{5}\right)$ and potassium $\left(\mathrm{K}_{2} \mathrm{O}\right)$ application of $30 \mathrm{~kg} \mathrm{ha}^{-1}$ and $60 \mathrm{~kg} \mathrm{ha}^{-1}$, respectively. To obtain nitrogen (according to each treatment), potassium chloride, superphosphate, and urea were used as sources. For both the recommendation of lime content and fertilizer, the recommendations by Ipa (2008) were followed. 


\section{Experimental design and treatments}

The treatments consisted of four types of water management $(\mathrm{M})$ and five doses of nitrogen $(\mathrm{N})$. Water managements were determined according to the culture's evapotranspiration, namely: $\mathrm{M}_{0}=14,980, \mathrm{M}_{1}=16,140, \mathrm{M}_{2}=17,390$ and $\mathrm{M}_{3}=$ $18,540 \mathrm{~m}^{3} \mathrm{ha}^{-1}$, the accumulated rainfall and the initial water volume $\left(13,600+1,380 \mathrm{~m}^{3} \mathrm{ha}^{-1}\right)$ being included in these managements. Nitrogen doses were determined based on Ipa (2008) recommendations for cane plant, namely, a standard dose of $40 \mathrm{~kg} \mathrm{ha}^{-1}$. The doses were defined as $\mathrm{N}_{0}=0, \mathrm{~N}_{1}=$ $20, \mathrm{~N}_{2}=40, \mathrm{~N}_{3}=80$ and $\mathrm{N}_{4}=120 \mathrm{~kg} \mathrm{ha}^{-1}$, arranged in strips and outlined in randomized blocks with four replications.

\section{Irrigation management}

The irrigation system used was the "line source sprinkler system" (sprinkler line), according to the methodology developed by Hanks et al. (1976). The system consisted of a central line with seven sprinklers spaced every 15 meters on a pipe located in the center of the experimental area. The sprinklers were KS 1500 - PLONA type mini-gun, with 16.0 $\times 5.0 \mathrm{~mm}$ diameter sprinklers, an operating pressure of 25 mca, a nominal flow rate of $13.61 \mathrm{~m}^{3} \mathrm{~h}^{-1}$ and wet diameter of $60 \mathrm{~m}$.

The relation between the reference management $\mathrm{M}_{2}(100 \%)$ and the others, as well as the management applied in each treatment, was obtained by evaluations of the irrigation system. The tests for measuring water volumes consisted of distribution lines with collectors perpendicular to the line of sprinklers, five collectors in each plot, spaced $1 \mathrm{~m}$ apart, distributed in each experimental block between planting lines, being the managements defined by average water volume collected in the five collectors (Table 3 ).

Irrigation was carried out when the difference between the sum of daily crop evapotranspiration (ETc) and rainfall in the period reached $40 \%$ of the total soil water available. To determine the availability of total soil water, the results of $\Theta_{\text {CC }}$, the $\Theta_{\text {PMP }}$ of soil, and the depth of the root system were considered. Data of water balance during the cultivation of plant cane are shown in Fig. 6.

The daily evapotranspiration of the culture (ETc; mm) was calculated by the following equation:

$\mathrm{ETc}=\mathrm{ECA} \cdot \mathrm{Kp} \cdot \mathrm{Kc}$

Where;

$\mathrm{ECA}=$ Class A tank evaporation, $\mathrm{mm}$;

$\mathrm{Kp}=$ Class A tank coefficient;

$\mathrm{Kc}=$ culture coefficient.

Kp values were obtained from wind speed, relative humidity and evaporation data of the class A tank, installed near the experimental area, with a $10 \mathrm{~m}$ low border vegetation (Doorenbos and Pruitt, 1976). For Kc, values recommended by Doorenbos and Kassam (1994) were used for the plant's development stages, aiming to determine ETc in each of them (Table 4).

In the first three months of the crop cycle, one uniform irrigation was made in all treatments, totaling a volume of $1,380 \mathrm{~m}^{3} \mathrm{ha}^{-1}$, because the planting was done in the summer, the driest time of the year, in order to ensure uniformity of sprouting and establishment of plants, using the mobile cylinder spraying system with a 4-inch nozzle diameter and a flow of $54 \mathrm{~m}^{3} \mathrm{~h}^{-1}$, under a pressure of a $40 \mathrm{~m}$ water column. Then, the application of different managements was initiated using a line source sprinkler system.

At 270 DAP, the irrigation was interrupted, causing water stress in culture. Water stress aimed to induce maturation and concentration of sugar, because, according to Doorenbos and Kassam (1994), during the maturation period, sugarcane requires low water content in the soil.

\section{Evaluating characteristics}

To detect the concentrations of nitrogen, phosphorus and potassium, the aerial parts of the plants were collected at the end of the cycle (349 days after planting). The data was collected from central plants in the middle of the external line (1st, 2nd, 9th and 10th lines) of each plot so that different water managements and nitrogen levels were considered. Ten plants were randomly taken for analysis. The aerial part of the plant was separated into leaf, tip and culm. After being separated, this material was triturated in a forage machine and then samples were pulled out. They were stored in previously identified paper bags and taken to an oven with forced air circulation at $65^{\circ} \mathrm{C}$ until reaching a constant weight. The dried samples were processed in a Wiley mill, and the concentrations of nitrogen, phosphorus and potassium were determined. To obtain the concentrations of nutrients, nitric (phosphorus and potassium) and sulfuric (nitrogen) digestions were performed, according to the methodologies of Embrapa (2009) and Bezerra Neto and Barreto (2011), respectively. Nitrogen was determined by the Kjeldahl distiller method, the concentration of potassium by flame photometry technique, and phosphorus by the colorimetric method of molybdate-vanadate in a spectrophotometer (Bezerra Neto and Barreto, 2011). Quantities of accumulated nutrients were calculated as the product of dry biomass versus the concentration of nutrients in each organ of the plant, converted to $\mathrm{kg} \mathrm{ha}^{-1}$, and multiplying it by the number of plants in each treatment.

\section{Statistical analysis}

The data were submitted to a normality test (Shapiro-Wilk), and subsequent analysis of variance and regression by $\mathrm{F}$ test at $5 \%$ probability using the SISVAR v 5.0 software (Ferreira, 2003).

\section{Conclusions}

In the light of the results of this study, it is concluded that availability of water provided an increase in leaf dry biomass accumulation, and nitrogen fertilization increased leaf and culm dry biomass accumulation of sugarcane. Nitrogen fertilization at planting increased the accumulation of nitrogen and phosphorus in various organs of the plant, and of potassium in sugarcane leaves. The nutrients most accumulated by plants were, in order of magnitude, nitrogen>potassium>phosphorus, in larger amounts in the culm. Water availability increased accumulation of potassium in sugarcane leaves.

\section{Acknowledgements}

The CAPES (Higher Education Personnel Improvement Coordination) for providing a scholarship to the first author during the period of the doctorate. CNPq (National Council for Scientific and Technological Development) grants the Productivity second Survey, to the third, fifth and sixth authors. At UFRPE (Rural Federal University of Pernambuco) and EECAC (Experimental Station Cane Sugar of Carpina) for technical support, and for allowing the research within their facilities. 


\section{References}

Almeida Júnior AB, Nascimento MFS, Silva FBV, Gomes WA (2011) Soil fertility and uptake of nutrients by sugarcane fertilized with filter cake. Rev Bras Eng Agríc Ambient. 15(10): 1004-1013.

Benett CGS, Buzetti S, Benett KSS, Texeira Filho MCM, Costa NR, Maeda AS, Andreotti M (2013) Amount of nutrients in stalk of sugar cane as a function of sources and doses of manganese. Rev Semin Ciênc Agrár. 34(3): 1077-1088.

Bezerra Neto E, Barreto LP. Methods of Chemical Analysis in plants. Recife: UFRPE, University Press. 267p.

Bologna-Campbell I, Franco HCJ, Vitti AC, Faroni CE, Costa MCG, Trivelin PCO (2013) Impact of Nitrogen and Sulphur Fertilizers on Yield and Quality of Sugarcane Plant Crop. Sugar Tech. 15(4): 424-428.

Bonnett GD, Hewitt ML, Glassop D (2006) Effects of high temperature on the growth and composition of sugarcane internodes. Aust J Agric Res.57(10): 1087-1095.

Brar MS, Bijay-Singh, Bansal SK, Srinivasarao CH (2011) Role of potassium nutrition in nitrogen use efficiency in cereals. Eifc 29: 20-27.

Calheiros AS, Oliveira MW, Ferreira VM, Barbosa GVS, Costa JPV, Lima GSA, Aristidis EVS (2011) Nutrients accumulation and sucrose production of two sugarcane varieties in the first regrowth related to phosphorus doses. Stab. 29(3): 34-37.

Campbell MK (2000) Biochemistry. $3^{\text {th }}$ Edition. Porto Alegre: Artmed.751p.

Carmo GA, Oliveira FRA, Medeiros JF, Oliveira FA, Campos MS, Freitas DC (2011) Leaf content, accumulation and partitioning of nutrients in pumpkin crop irrigated with saline water. Rev Bras Eng Agríc Ambient. 15(5): 512-518.

Carvalho CM, Azevedo HM, Dantas Neto J, Farias CHA, Silva CTS, Gomes Filho RR (2009) Rendimento de açúcar e álcool da cana-de-açúcar submetida a diferentes níveis de irrigação. Rev Bras Ciênc Agrár. 4(1): 72-77.

Dalri AB, Cruz RL, Garcia CJB, Duenhas LH (2008) Subsurface drip irrigation on sugarcane yield and quality. Irriga. 13(1): 111.

Dantas Neto J. Figueredo JLC, Farias CHA, Azevedo HM, Azevedo CAV (2006) Response of sugarcane, second leaf, to irrigation levels and topdressing manuring. Rev Bras Eng Agríc Ambient.10(2): 283-288.

Doorenbos J, Kassan A H (1994) Water effect on crop yield. Campina Grande: UFPB. 306p.

Doorenbos J, Pruitt WO (1976) Water requirements of crops. Rome: FAO. 193 p.

Embrapa (1997) Manual methods of analysis of soils. $2^{\text {th }}$ Edition. Rio de Janeiro: Embrapa. 212p.

Embrapa (2009) Manual of chemical analyzes of soils, plants and fertilizers. $2^{\text {th }}$ Edition. Brasília: Embrapa. 627p.

Embrapa (2013) Brazilian system of soil classification. $3^{\text {th }}$ Edition. Brasília: Embrapa. 353p.

Farias CHA, Fernandes PD, Azevedo HM, Dantas Neto J (2008) Growth indices of irrigated and non-irrigated sugar cane in Paraiba, Brazil. Rev Bras Eng Agríc Ambient. 12(4): 356-362.

Ferreira DF (2003) Manual de programas de análises estatísticas e planejamento de experimentos: sisvar, versão 5.0 (Build 67). Lavras: DEX/FLA. 66p.

Figueiredo PAM (2006) Particularities about potassium. Stab. 24(6): 25.

Franco HCJ, Bologna IR, Faroni, CE, Trivelin, PCO (2007) Macronutrients accumulation in sugarcane crop related to nitrogen fertilization and cultural residues incorporated to the soil at planting. Bragantia. 66(4): 521-526.

Franco HCJ, Trivelin PCO, Faroni CE, Otto R (2010) Stalk yield and technological attributes of planted cane as related to nitrogen fertilization. Sci Agric. 67(5): 579-590.

Freitas AS, Silva ARA, Bezerra FML, Ferreira CS, Andrade RR (2012) Vegetative growth of sugar cane (Saccharum officinarum L.) irrigated with water from treated domestic sewage. Conex Ciênc Tecnol. 6(1): 27-43.

Hanks RJ, Keller J, Rasmussen VP, Wilson GD (1976) Line source sprinkler for continuous variable irrigation-crop production studies. Soil Sci Soc Am J. 40: 426-429.

Ipa (2008) Fertilizer recommendations for the state of Pernambuco. $2^{\text {th }}$ Edition. Recife: Agronomic Institute of Pernambuco. 212p.

Lawlor DW, Cornic G (2002) Photosynthetic carbon assimilation and associated metabolism in relation to water deficits in higher plants. Plant Cell Environ. 25(2): 275-294.

Malavolta E (2006) Manual of mineral nutrition of plants. São Paulo: Ceres. 638p.

Marschner P (2012) Marschner's mineral nutrition of higher plants. $3^{\text {th }}$ Edition. New York, Academic Press. 651p.

Minami K, Haag HP (2003) The tomato. $2^{\text {th }}$ Edition. Campinas: Foundation Cargill.

Oliveira ECA, Freire FJ, Oliveira RI, Freire MBGS, Simões Neto DE, Silva SAM (2010a) Nutrient extraction and export by fully irrigated sugarcane varieties. Rev Bras Ciênc Solo. 34: 13431352

Oliveira ECA, Freire FJ, Oliveira RI, Oliveira AC, Freire MBGS (2011b) Accumulation and allocation of nutrients in sugar cane. Rev Ciênc Agron. 42(3): 579-588

Oliveira ECA, Oliveira RI, Andrade BMT, Freire FJ, Lira Júnior MA, Machado PR (2010b) Growth and dry matter production in sugarcane varieties grown under full irrigation. Rev Bras Eng Agríc Ambient. 14(9): 951-960.

Oliveira ECA, Freire JF, Oliveira AC, Simões Neto DE, Rocha AT, Carvalho LA (2011a) Productivity, water use efficiency, and technological quality of sugarcane subjected to differents water regimes. Pesq Agropec Bras. 46(6): 617-625.

Otto R, Franco HCJ, Faroni CE, Vitti AC, Trivelin PCO (2009) Sugarcane root and shoot phytomass related to nitrogen fertilization at planting. Pesq Agropec Bras. 44(4): 398-405.

Prado RM, Franco CF, Puga AP (2010) Macronutrient deficiencies in soybean cv. BRSMG 68 (Vencedora) cultivated in nutritive solution. Com Sci. 1(2): 114-119.

Rengel M, Gil F, Montaño J (2011) Crecimiento y dinámica de acumulación de nutrientes en caña-de-azúcar. Bioagro. 21(3): 43-50.

Robinson N, Gamage H, Whan A, Fletcher A, Brackin R, Holst J, Lakshamanan P, Silva LCF, Casagrande JC (1983) Mineral nutrition of sugarcane (macronutrients). In: Orlando Filho J (ed) Nutrition and fertilization of sugarcane, Piracicaba, São Paulo.

Taiz L, Zeiger E (2013) Plant Physiology. 5. ${ }^{\text {th }}$ Edition. Porto Alegre: Artmed. 918p.

Trivelin PCO, Vitti AC, Oliveira MW, Gava GJC, Sarriés GA (2002) Nitrogen utilization and sugarcane (plant cane) yield on a sandy soil with incorporated crop residues. Rev Bras Ciênc Solo. 26(3): 637-646.

Vale DW, Prado RM, Avalhães C, Hojo RH (2011) Macronutrients omission in the nutrition and growth of sugarcane grown in nutritious solution. Rev Bras Ciênc Agrár. 6(2): 189-196.

Vale DW, Prado RM, Cantarella H, Fonseca IM, Avalhães CC, Correia MAR, Barbosa, MP (2013) Ammonium and nitrate in soil and ratoon sugarcane grown in function of nitrogen on oxisol. J Plant Nutr. 36(2): 201-213. 